\title{
DEGS2 wt Allele
}

National Cancer Institute

\section{Source}

National Cancer Institute. DEGS2 wt Allele. NCI Thesaurus. Code C104179.

Human DEGS2 wild-type allele is located in the vicinity of $14 q 32.2$ and is approximately 14 $\mathrm{kb}$ in length. This allele, which encodes sphingolipid delta(4)-desaturase/C4-hydroxylase DES2 protein, plays a role in sphingolipid biosynthesis. 